\title{
Modernidad de la Historia verdadera de la conquista de la Nueva España de Bernal Díaz del Castillo. Refutación y afirmación
}

\section{Modernity of the Historia verdadera de la conquista de la Nueva España by Bernal Díaz del Castillo. Refutation and assertion}

\author{
Juan García Única \\ Universidad de Granada \\ jggu@ugr.es \\ ORCID iD: http://orcid.org/0000-0001-5149-9399
}

\section{RESUMEN}

En este trabajo analizamos la modernidad de la Historia verdadera de la conquista de la Nueva España de Bernal Díaz del Castillo. Modernidad que no debe ser entendida en tanto reivindicación del autor como uno de los primeros novelistas de la literatura hispánica, según una conocida tesis de Carlos Fuentes, sino en tanto resultado de un peculiar modo de enunciación que privilegia la mirada literal sobre la mirada alegórica de la crónica. Para ello nos valemos del estudio comparativo de la Historia verdadera y la Historia de la conquista de México, del cronista contemporáneo de Díaz del Castillo, y capellán de Hernán Cortés, Francisco López de Gómara.

Palabras Clave: Bernal Díaz del Castillo; Francisco López de Gómara; modernidad; mirada literal; mirada alegórica.

\begin{abstract}
In this paper we analyze the modernity of the Historia verdadera de la conquista de la Nueva España by Bernal Díaz del Castillo. Modernity that should not be understood as the vindication of the author as one of the first novelists of the Hispanic literature, according to a wellknown Carlos Fuentes' thesis, but as the result of a particular way of enunciation that favours the literal view of the world before the allegorical one of the chronicle. In order to do this, we carry out a comparative study of the Bernal's Historia verdadera and the Historia de la conquista de México by the contemporary chronicler of Bernal Díaz del Castillo, and chaplain of Hernán Cortés, Francisco López de Gómara.
\end{abstract}

Key words: Bernal Díaz del Castillo; Francisco López de Gómara; Modernity; Literal view; Allegorical view. 


\section{INTRODUCCIÓN: HACIA UNA NUEVA VIEJA LECTURA}

Si bien no el más importante, el ensayo de Carlos Fuentes sobre Bernal Díaz del Castillo y su épica vacilante ha sido, casi con toda seguridad, el trabajo cuya huella ha dejado un trazo más reconocible en el rumbo por el que parece haberse decantado una nada desdeñable parte de la crítica bernaldiana en las últimas décadas. Sin dificultad se encontrarán en él afirmaciones que han contribuido a moldear nuestra percepción actual del autor de la Historia verdadera de la conquista de la Nueva España, destacando entre ellas, quizá, la que establece que su memoria «es la memoria moderna del novelista, y está inmersa en diversos afectos narrativos inseparables de la novela en el momento de su gestación» (Fuentes 1990: 80)․․ Se diría obvio que, de un tiempo a esta parte, con Bernal Díaz del Castillo se ha pasado del encajonamiento en la tradición de los cronistas de Indias a su veneración poco menos que como uno de los más singulares y tempranos novelistas de la literatura hispánica. En lo que va de siglo y de milenio, y aunque cada cual a su manera, algunas de las monografías más destacadas que se le han consagrado, como es el caso de las de Verónica Cortínez (2000) u Oswaldo Estrada (2009), por citar solo dos ejemplos relativamente recientes, coinciden en ubicar al autor nacido en $\mathrm{Me}$ dina del Campo en la senda del protonovelista anticipador de formas, técnicas y concepciones de la escritura propias no ya del escritor moderno (entendiendo por tal a un autor del siglo XVI, sin más), sino incluso del novelista abiertamente contemporáneo o postmoderno.

No deja de llamar la atención que Verónica Cortínez, en un libro centrado en buena medida en los sutiles mecanismos psicológicos que se supone exhibe Bernal, empiece por establecer la siguiente comparación: «Al igual que Freud, quien se desplaza de la psicología al ámbito de las letras, Bernal, autor de una original memoria, se aleja de lo puramente histórico para ser en nuestros días la piedra de toque de una tradición literaria» (2000: 13). Mucho decir nos parece esto, aunque sea cierto, como la propia investigadora señala, que la obra bernaldiana se estudie con cierta insistencia en tanto parte del canon literario nacional de países como México. Cortínez, asumiendo como rasgo más destacado de la Historia verdadera la incertidumbre, dice haberse propuesto con su estudio un propósito doble. En primer lugar, intenta mostrar una sofisticada -y acaso forzada - relación entre la memoria y la escritura, entre la veracidad de los hechos y la fragilidad de su recuerdo, o entre la monumentalidad de la Historia y la fragilidad del lenguaje, sin renunciar a cierto sesgo psicologista:

1 Entre esos afectos que señala Fuentes (1990: 74) —y la cursiva que reproduzco en estas citas será suya en todo momento- habría que contar el amor por la caracterización, el que se da por el detalle (especialmente el detalle que desacraliza las figuras épicas) y el amor por el chisme. 
Para desautorizar a los cronistas que nunca pasaron a Indias y defenderse de posibles críticas, el autor apela constantemente al lector. Sin embargo, la imposibilidad de confiar plenamente en esa tentativa de historia desplaza el valor de la obra hacia otros territorios en los que se privilegia la imaginación. Lo verídico del texto cede ante un modo de contar que se funda involuntariamente en la fragilidad de la memoria. Bernal, en la vejez, trata de recuperar el pasado, pero en esa búsqueda del tiempo perdido intuye que recordarlo todo es imposible. Más aún, incluso cuando fluye la memoria, el proceso de escritura es difícil, frustrante, problemático. Al intentar el traslado minucioso de la conquista de la Nueva España a las páginas de su manuscrito, Bernal presiente la monumentalidad de su empresa y, en última instancia, la insuficiencia del lenguaje en la representación de la realidad (Cortínez 2000: 16).

Ya es bastante difícil determinar si Bernal presintió o no en su momento la insuficiencia del lenguaje en la representación de la realidad, problema tal vez en demasía moderno para el abanico de preocupaciones que sí debieron concernir a un viejo soldado de Cortés en busca de reconocimiento, pero en todo caso predica Cortínez (2000: 18) de esa supuesta imposibilidad de recuperar el pasado que «no se trata de un simple testimonio de heroísmo, sino de una problemática cuya esencia es literaria», aproximándose claramente a la lectura de Carlos Fuentes ${ }^{2}$. Y de hecho es tal lectura en clave literaria lo que señala la autora como segundo propósito de su estudio, que no sería sino el de «descubrir el mecanismo a través del cual la Historia verdadera, al alejarse de la historia y acercarse a lo literario, se convierte en uno de los textos en los que se fundamenta el sistema de la literatura hispanoamericana» (ibíd.: 20)3

Como «análisis postmoderno de la Historia verdadera en relación con el género de la novela» define Oswaldo Estrada (2009: 13) su propio trabajo, que no por nada lleva el explícito título de La imaginación novelesca. Bernal Díaz

${ }^{2}$ Sirva como ejemplo el señalar que, si Carlos Fuentes hablaba de los «afectos narrativos» de Bernal, Verónica Cortínez (2000: 18) establece una relación no menos gratuita, aunque muy por demostrar, entre afectividad y tradición literaria: «En el proceso de recordar y escribir se revela una vocación insospechada; la historia de Bernal, alejada de las convenciones, está marcada por el asombro y la nostalgia. Ante la muerte cercana, esa tentativa de capturar con precisión afectiva un tiempo remoto y un espacio misterioso vincula la Historia verdadera con los motivos tradicionales de la literatura».

${ }^{3}$ Con un problema, a nuestro entender casi inevitable en el terreno que había dejado abonado la tesis de Fuentes, y es que Cortínez, si bien minimiza en el libro arriba mencionado la difícil pero fundamental relación de Bernal Díaz del Castillo con la obra de López de Gómara, ya en un trabajo anterior (Cortínez 1991) no había dudado en establecer un diálogo en cierto modo esencialista — pues sea lo que sea lo que ella llama «memoria original» está claro que lo percibe como una forma esencial de la tradición literaria- con un texto tan increíblemente alejado de la lógica de la escritura bernaldiana como pueda serlo La casa de los espíritus, de Isabel Allende. Tampoco extraña la sugerencia de reconocer en la Historia verdadera el anticipo de ciertos aspectos de la obra de Cortázar o Borges, quienes pasan así a ser, ellos también, una sorprendente clave de lectura de nuestro autor. 
del Castillo entre géneros y épocas. En ese afán por convertir al de Medina del Campo en una suerte de protonovelista, Estrada se muestra algo más concreto que Cortínez, sin que su tesis principal deje de parecernos sustancialmente la misma que la de Carlos Fuentes:

Vista desde la posteridad, la relación o historia verdadera conserva ciertas dimensiones que hoy podemos reconocer como novelescas, por las resonancias que éstas tienen con el mundo ambivalente e inacabado de la novela moderna. En el entramado de sus largas oraciones que tratan de contar la verdad desde el punto de vista de un testigo ocular, así como en sus dichos populares e interrupciones narrativas propias del relato oral, hallamos una prosa efervescente que se distancia de las convenciones sobre el arte de historiar en el momento histórico en que se compone la obra. A diferencia de un historiador o cronista oficial, el viejo Bernal que se presenta al inicio de la Historia verdadera nos hace trabajar con él para completar el significado de aquello que quiere contarnos. Debido a este diálogo nutrido por su información y nuestras expectativas, en sus páginas descubrimos la psicología de una época, un logrado esfuerzo por controlar varias historias a la vez, la ambientación sutil del espacio americano, la construcción ingeniosa de personajes que cambian a lo largo de la trama, el ensamblaje calculado del suspenso, el desarrollo de acciones encontradas, las voces en jaque de distintivas figuras históricas y el andar de éstas por un mundo ancho y ajeno, dominado por situaciones impredecibles (Estrada 2009: 18).

Sin duda que, aunque solo sea por su pretensión primera de redactar un memorial de méritos, es bastante complicado encajar a Bernal en la categoría de historiador, y mucho más en la de cronista oficial, pero no por ello concluiremos que los rasgos que señala Oswaldo Estrada como definitorios de la novela, y que con un poco de esfuerzo pudieran aplicarse a la Historia verdadera lo mismo que a otras producciones que le son coetáneas, lo conviertan instantáneamente en un novelista moderno. Con todo, Estrada, que también delimita un propósito doble en su ensayo, toma la precaución de empezar por adoptar como primer plano crítico el situar «al autor en el momento histórico e historiográfico en que produce su manuscrito, revalidando no solo su originalidad sino también los estudios bernaldianos que hasta la fecha han iluminado nuestro acercamiento a la Historia verdadera» (ibíd.: 20). Más problemático se nos presenta el empeño — otra vez en la línea de la lectura literaria — de dar paso a un «segundo estado crítico», el cual pasaría por el análisis de los elementos de la Historia que Estrada considera novelescos, y que según él «le conceden una visita pasajera por el espacio multifacético de la novela moderna y propician su inscripción explícita en la narrativa contemporánea de México» (ibíd.).

Lo sorprendente es que, a pesar de estar formulando sus tesis tras la irrupción del trabajo de Carlos Fuentes y de la propia Verónica Cortínez, a Estrada (ibíd.: 20) le parezca estar ante un documento «raras veces estudiado como 
artefacto propiamente literario» ${ }^{4}$. Quizá este recelo se entienda mejor si consideramos que tanto Cortínez como Estrada plantean sus trabajos sin disimulos como respuesta a la posición defendida en su día por Margarita Zamora en un breve pero enjundioso artículo. Para Zamora (1987: 334), quien pone por delante la máxima de Yuri Lotman según la cual ningún texto escapa a la posibilidad de ser transformado en «literatura», el hecho de aplicar el calificativo de «literarios» a textos que en origen no lo eran constituye un anacronismo, y de ahí que sin llegar a mencionar siquiera la obra de Bernal Díaz del Castillo considere que solo a partir de un concepto de reclasificación asociado a circunstancias históricas muy concretas — «The resurgence of interest in the works of the colonial period coincides with romanticism and the push toward political emancipation from Spain» (Zamora 1987: 340) — se llegue a construir la imagen de una suerte de Edad Media literaria, es decir, de una protoliteratura nacional mexicana o hispanoamericana, representada en los cronistas de Indias.

Sea como sea, defenderemos que el problema menos estimulante en Bernal acaso lo constituya su inscripción en un determinado esquema genérico; esquema por lo demás surgido de una coyuntura muy distinta — ahí no podemos sino darle la razón a Zamora - a la que conoció Bernal en su tiempo. Y sin embargo sí pensamos que hay una lectura posible de Bernal en la cual se reconoce la aparición de un requisito imprescindible para la formulación de la literatura moderna, y de la modernidad en general, que muy poco tiene que ver con este debate en torno a su inscripción genérica que tan someramente acabamos de resumir: la enunciación de un «yo» cuya legitimación pasa ya no por el reconocimiento de un mundo en el que se supone están inscritas las signaturas de la divinidad, como de alguna manera se da por supuesto en la enunciación de la crónica, sino por la propia literalidad de la mirada de un sujeto que construye un objeto que no le está dado previamente. De hecho, no descartaríamos que sea la extrañeza de ese yo que se formula a sí mismo ante el propio objeto construido lo que esté detrás del titubeo que parece mostrar Bernal en su escritura, nunca del todo acabada y siempre en proceso de ir más allá del memorial de méritos que empezó siendo.

En el caso de la Historia verdadera pensamos que podría hablarse, sin necesidad de ser imprecisos, de un auténtico viraje desde su primera conside-

${ }^{4}$ Lo cual encierra una contradicción se mire por donde se mire, desde el momento en que muy poco antes escribe: «En ningún momento trato de probar que la obra de Bernal es una novela, porque sería anacrónico hacerlo» (Estrada 2009: 20). Con todos los matices que se quiera, una vez más cabría señalar que no hay gran diferencia entre tratar de demostrar que la Historia verdadera es una novela y tratar de demostrar que es producto de una imaginación esencialmente novelesca. Una y otra posición supone, a nuestro juicio, una deshistorización flagrante del lugar enunciativo de la obra, que es lo que mal que bien trataremos de delimitar aquí. 
ración historiográfica hacia la tendencia última de primar la lectura literaria. Como consecuencia, Bernal Díaz del Castillo hace ya mucho que no es considerado un mero redactor de memoriales y otros documentos relativos a la tupida burocracia de las Indias, sino un autor capital del canon de la literatura española y por supuesto de la hispanoamericana ${ }^{5}$. La perspectiva que adoptaremos en esta aproximación, sin embargo, ni pretende renegar de la historia ni pretende hacerlo de la literatura, toda vez que entendemos que uno de los problemas más interesantes e ineludibles que el texto de Bernal le pone delante de los ojos al investigador de la segunda no es otro que el del surgimiento que se vislumbra en sus páginas, casi como en ninguna otra parte, de un tipo de subjetividad o de un modo de enunciación del yo que andando el tiempo habrían de ser los propios del escritor moderno (y solo moderno, sin pre- ni post-). Se comprenderá, por otra parte, que el estudio de los modos de enunciación literaria no deja de ser ante todo el estudio de un problema eminentemente histórico. $\mathrm{O}$, dicho de otra manera, resulta imposible determinar el lugar enunciativo a partir del cual fue posible la escritura de la Historia verdadera de la conquista de la Nueva España si se renuncia a indagar, a su vez, en las condiciones históricas que la hicieron concebible en su momento y que nos la explican hoy.

Nadie que se marque ese propósito de entrada las tiene todas consigo, desde luego, pero es verdad que en el caso concreto de Bernal Díaz del Castillo partimos con la ventaja de disponer de una serie de materiales y testimonios, exhumada a lo largo de mucho tiempo por una venerable y bien nutrida tradición crítica, que facilita considerablemente la labor. Sin ser nuevos, tales documentos sí se prestan en su mayor parte a ser leídos y releídos en busca de ángulos inéditos, como así haremos, aunque no sin antes especificar que, en aras a determinar cómo y frente a qué surge la modernidad de la Historia verdadera, contamos en este asunto con la irrupción - feliz casualidad histórica para nosotros, aunque no tanto para Bernal- de esa especie de antagonista involuntario de nuestro autor que es Francisco López de Gómara y su Historia de la conquista de México (involuntario, decimos, porque entre otras cosas Gómara no leyó nunca a Díaz del Castillo ni parece siquiera que tuviera noticia de la existencia del viejo soldado de Cortés en la remota ciudad de Guatemala). No se insiste lo bastante en lo que de fundamental y decisivo hay en

5 Aparte de los debates que hemos señalado, valga por caso el que la Historia verdadera de la conquista de la Nueva España sea hoy por hoy uno de los ciento once volúmenes que componen «el núcleo esencial de la tradición literaria española e hispanoamericana hasta finales del siglo XIX», según criterio de la Real Academia Española, que lo incluye como número 36 de su Biblioteca Clásica Hispánica. Salvo en los casos en los que explícitamente se indique otra cosa, será la monumental edición de Guillermo Serés para dicha colección (Díaz del Castillo 2011) la que sigamos en las citas, limitándonos a consignar el número de capítulo y de página. 
esta cuestión: cuando Bernal se encuentre redactando su memorial de méritos, uno de tantos en principio, irrumpirá en escena una Historia frente a la cual nuestro autor se verá obligado a apostillarle el adjetivo de verdadera al título de la suya. O, si prefiere ver de esta manera, diremos que cuando Gómara dé a la imprenta una suerte de cronicón en alabanza de Hernán Cortés, Bernal reaccionará pergeñando un texto que ya sí que no podrá ser considerado simplemente uno más.

Resulta una obviedad señalar que lo que de nuevo y asombroso hay en la Historia verdadera de la conquista de la Nueva España se acaba desvelando en este diálogo no correspondido de Bernal Díaz del Castillo con Francisco López de Gómara. Porque desde luego no fue correspondido, pero tanto da, pues que no haya diálogo no significa que deje de haber dialéctica, y además no es precisamente poco lo que Bernal se trae y nos trae de vuelta de ese envite: ni más ni menos que una de las primeras enunciaciones reconocibles en nuestras letras del yo moderno. Vayamos poco a poco.

\section{Ni «CUENTOS VIEJOS, NI HISTORIAS DE ROMANOS»: A PROPÓSITO DE un prólogo dudoso de Bernal Díaz del Castillo a SU Historia VERDADERA DE LA CONQUISTA DE LA NUEVA ESPAÑA}

En la Biblioteca Nacional de Madrid se hallan dos impresiones de la Historia verdadera de la conquista de la Nueva España, ambas del siglo XVII. Una y otra ofrecen en la portada casi los mismos datos, aunque entre las pequeñas diferencias que guardan entre sí se cuenta la de que una lleva fecha y la otra no. La que la lleva dice haber salido de la Imprenta del Reyno en el año de 1632 y no incluye grabado alguno, pero sí una orla en la portada; la que no la lleva, por su parte, declara provenir también de las mismas prensas y se acompaña de un grabado que nos ofrece pistas bien significativas.

Se ha discutido mucho cuál de las dos ediciones debe ser considerada la princeps, si bien hace poco el problema parece haberse resuelto para siempre, de modo que hoy puede afirmarse que la edición sin grabado, pero con indicación de fecha concreta, pudo ser la contrahecha, mientras que la que no incluye fecha, pero sí grabado, la editio princeps $^{6}$. Decíamos, sin embargo, que el

${ }^{6}$ Así lo acepta en el estudio a su edición de la obra Guillermo Serés (2011a: 1223-1224), quien no obstante remite a una observación publicada en el blog Marcas tipográficas por Carlos Fernández, que valiéndose de una sencillez y sensatez apabullantes zanja el problema: «Realmente sólo manejando unos conocimientos tipográficos básicos resulta claro apreciar que la edición contrahecha no pudo ser impresa en el año 1632 y tuvo que serlo mucho tiempo después, posiblemente a finales de siglo o principios del siguiente. Uno lee el título de esta edición y se encuentra con la palabra "NUEVA": las primeras úes mayúsculas en España se empiezan a ver en algunos impresos de los años 70 del siglo XVII (seguramente 
grabado no debería pasarnos desapercibido y por ello será conveniente que le dediquemos alguna palabra. En primer lugar, causará sorpresa al neófito comprobar que no hay en él la más mínima referencia a Bernal, como sí la encontramos, en cambio, a dos personajes decisivos dentro de la peculiar suerte editorial de la Historia verdadera: Hernán Cortés (D. Fernando Cortes, en el grabado) y el P. M. Bartolomé de Olmedo, fraile de la Orden de la Merced que, como Díaz del Castillo, acompañó a Cortés en su expedición por el Nuevo Mundo. Aparece el primero, sobre el que se lee la leyenda MANU, sosteniendo en su mano izquierda el bastón de capitán y en la derecha un escudo con lo que parece ser la escena de Moctezuma entregándole las llaves de la ciudad de Tenochtitlán; sobre el segundo se lee la leyenda ORE, pero en este caso es la cruz lo que sostiene en su mano derecha, portando en la izquierda un escudo en el cual se le muestra bautizando a los aztecas. La conjunción de ambos representa la llegada a los nuevos territorios del Imperio de Cristo, necesitado por igual de la cruz que de la espada. La cuestión es que no deja de resultar llamativo que sea un personaje muy menor, fray Bartolomé de Olmedo, quien ocupe, en detrimento de un Bernal que ni aparece, lugar tan preeminente junto a Cortés en esta primera impresión del texto.

Sin embargo tiene razón Guillermo Serés cuando afirma que «las memorias de los hechos de armas de Bernal se hubiesen olvidado en los rimeros del Archivo de Indias de no haberles acompañado un hombre de letras, un fraile mercedario que estuvo siempre en segundo plano» (Serés 2011b: XII), pues fue la presencia de tal fraile la que motivó a su hermano de hábito del siglo siguiente, fray Alonso Remón, a reivindicar el papel en la evangelización de las Indias de una orden minoritaria, la de los mercedarios, por entonces en decadencia frente a la pujanza de dominicos, franciscanos y, más tarde, jesuitas. Si conservamos la memoria de Bernal es en buena medida gracias a este peculiar homenaje que un fraile le rinde a otro, pero no solo eso: de no ser por la iniciativa de fray Alonso Remón, de seguro no conoceríamos hoy el fundamental comienzo de la versión impresa en 1632, dado que no figura este en ninguno de los manuscritos conservados.

de tipos importados de Europa donde en algunos países como Holanda y Alemania ya se utilizaba desde varias décadas antes). Dentro del libro hay otros ejemplos de úes mayúsculas y un examen más en profundidad de otros elementos, por ejemplo, la orla tipográfica de la portada o la marca de agua, también son propios de un año mucho más avanzado que el de 1632» (Carlos Fernández, "Sobre la Historia verdadera de la conquista de la Nueva España», en http://marcasdeimpresor.blogspot.com.es/2010/04/sobre-la-historia-verdaderade-la.html, consultado el 21 de octubre de 2014, aunque la entrada es de 2010). Al margen de estas juiciosas observaciones, que sitúan la portada con fecha más allá de 1632, parece más plausible aun lo que dice Fernández si además tenemos en cuenta la existencia de otros indicios que nos acercan el grabado de la portada a fecha más cercana a 1632: por ejemplo, el hecho de que esté firmado por Jean (o Juan) de Courbes, grabador parisino muerto en 1641 que vivió y ejerció su actividad en Madrid hasta al menos 1639. 
De hecho, y tal vez movido por un exceso de celo ecdótico, Guillermo Serés no lo ha publicado más que como nota a pie de página en su edición, suponiendo que el texto que manejó fray Alonso Remón para la suya fue una copia autógrafa de la primera redacción de $\mathrm{G}$ enviada por el presidente de la Audiencia de Guatemala, Francisco Villalobos, al Consejo de Indias en 1575 para su publicación. Sea como fuere, de lo que no cabe duda es de que el comienzo al que nos referimos no es otro que el que llegó a manos de fray Alonso Remón y, por ende, a la imprenta en 1632. Como entendemos que el fraile mercedario no pudo sacar de la nada las palabras que en algún momento Bernal tuvo forzosamente que escribir, defenderemos que es legítimo considerarlo, con todos los problemas que se quiera, tan prólogo de la Historia verdadera como los editados por Serés.

Ahora bien: ¿qué dice en él Bernal que deba interesarnos tanto aquí? En principio, hablamos de una más de esas pullas características que le propina de vez en cuando a Gómara para recordarle que, frente a la retórica y la exhibición de dominio de la auctoritas que se gasta el capellán, él, como viejo soldado, escribe amparándose en su propia condición de testigo de los hechos:

... que lo que en este libro se contiene, va mui verdadero, que como testigo de vista me hallè en todas las batallas è rencuentros de guerra: è no son cuentos viejos, ni Historias de Romanos de más de setecientos años, porque a manera de dezir, ayer passò lo que veran en mi Historia (Díaz del Castillo 1632: fol. 10)7

Dejando ahora a un lado otras consideraciones, nos preguntaremos qué significa que un viejo miembro de la compañía de Cortés le recuerde a un cronista peninsular que lo suyo no son - y la observación es decisiva-cuentos viejos ni historias de romanos. Para entender por qué en ese certero dardo se estaba cifrando la emergencia de un mundo nuevo, y no solo del Nuevo Mundo, es necesario antes saber cuál era el centro de la diana al que iba dirigido. Dicho de otro modo: es necesario precisar antes que nada desde qué lugar enunciativo escribía López de Gómara.

7 Dado que, como indicábamos, Guillermo Serés no ha incluido este prólogo dentro del cuerpo principal de su edición, todo lo que provenga de él lo citaremos siempre por la impresión que se conserva en la Biblioteca Nacional. La transcripción, incluidas las cursivas, es nuestra. Para el resto de citas de la Historia verdadera sí seguiremos escrupulosamente el texto establecido por Serés (Díaz del Castillo 2011), limitándonos a citar entre paréntesis el número de capítulo, cuando así proceda, seguido del número de página. 
3. CORTÉS «ENTRE LAS HISTORIAS DEL MUNDO»: UNA EXÉGESIS FIGURAL DE la dedicatoria a Martín Cortés de la Historia de la Conquista DE MÉxICO DE Francisco LóPEz DE Gómara

En 1552, en Zaragoza y en la Imprenta de Agustín Millán, aparece un extenso tomo a cargo de Francisco López de Gómara titulado Hispania Victrix. Historia General de Las Indias, cuya segunda parte, Historia de la Conquista de México, constituye en sí misma una obra dentro de la obra. La repercusión que conoce dicha Historia General de las Indias es rápida a lo largo del siglo XVI, como muestran las cuatro ediciones y un secuestro que siguen a su aparición, pues en efecto a la edición de Zaragoza le suceden la de Medina del Campo de 1553, por Guillermo de Millis, otra de nuevo en Zaragoza en 1554, por Pedro Bernuz, y dos en Amberes, también en 1554 y publicadas por J. Steelsio y Juan Lacio respectivamente. Son bastantes, sobre todo si tenemos en cuenta que las dos primeras - la de Zaragoza de 1552 y la de Medina del Campo de 1553 - habían sido retiradas de la circulación mediante cédula fechada el 17 de noviembre de 1553, sin que hoy en día estén claros los motivos de esta persecución ${ }^{8}$. Sea como fuere, a partir de un momento dado de 1554 la segunda parte de la obra ya empieza a editarse de manera independiente con el título de La conquista de México, alcanzando tres ediciones en el transcurso de ese mismo año: dos de nuevo en Amberes, por Martín Nuncio y Juan Bellero, y una tercera que retorna a Zaragoza y al primer editor, Agustín Millán.

Considerada de manera independiente, la segunda parte de la Hispania Victrix resulta tan orgánica por sí misma que el propio López de Gómara no duda en incluir en ella una dedicatoria al Marqués del Valle, cargo que en 1552 ya ostentaba don Martín Cortés, hijo del famoso conquistador. Ni el apellido ni el título nobiliario pueden serle ajenos a Gómara, quien optará en la mencionada dedicatoria por el motivo retórico de la distinción entre la hacienda y la honra. Su razonamiento es más bien previsible: la hacienda, que el segundo Marqués del Valle atesora por derecho de mayorazgo, tiene tanta vida y valor cuanto los tiene la riqueza; la honra, sin embargo, se bate en las arenas movedizas de la historia y está intrínsecamente unida a la fama. De este modo, Gómara le recuerda a Martín Cortés que la hacienda obliga a perpetuar la honra, justificando de paso la necesidad de los mayorazgos en tanto garantes de la hacienda ante las muchas particiones; pero en lo que insiste, sobre todo, es en que la historia y la fama duran mucho más que las riquezas, pues hasta

${ }^{8}$ Limitémonos a recordar las cuatro posibles causas que propone Valcárcel Martínez (1989: 11-12) en su aproximación a Gómara: la oposición del padre Las Casas; la supuesta reacción negativa de Martín Cortés (muy poco probable, dado que llegó a ser amigo del cronista); la independencia de criterio que muestra el autor; o las posibles y poco veladas críticas hacia la política del emperador Carlos V. 
los mayorazgos son susceptibles de acabarse «o por falta de casta o por caso de guerra, por lo que suele haber mudanza de señoríos» (López de Gómara 2000a: 39), mientras que a la historia «nunca le faltan amigos que la renueven, ni la impiden las guerras; y cuanto más se añeja, más se aprecia» (ibíd.).

En definitiva, lo que tenemos es el elogio retórico al uso de un personaje docto que pone su pluma al servicio de una casa señorial. La intención última es inscribir el nombre de los Cortés en la piedra, incidir en su importancia entre los hechos que merecen recordarse desde la Creación: «La conquista de México y conversión de los de la Nueva España, justamente se puede y debe poner entre las historias del mundo, así porque fue bien hecha, como porque fue muy grande» (López de Gómara 2000a: 40). Claro está que tal cosa no sería enunciable fuera de la concepción sacralizada de la historia de la que parte Gómara, quien como los cronistas medievales da por sentado en todo momento que cualquier escritura docta es glosa de la Escritura o variación de la auctoritas. Así leemos: «Son de Dios los reinos y señoríos: Él los mida, quita y da a quien y como le place, pues así lo dijo Él mismo por el Profeta» (López de Gómara 2000a: 39). Esto no deja de ser una glosa de cierto pasaje veterotestamentario, porque el Profeta aludido es sin duda Daniel: "Y el reino y el imperio y la grandeza de los reinos bajo los cielos todos serán dados al pueblo de los santos del Altísimo, Reino eterno es su reino, y todos los imperios le servirán y obedecerán» (Daniel, 7, 27).

Nos encontramos con que Gómara no por ser uno de los hombres más instruidos en las letras de humanidad de su tiempo deja de partir de una suerte de lectura figural del mundo que le lleva a enunciar su escritura en clave muy cercana a la de la crónica en el sentido más medieval del término. Si Bernal va a testimoniar su experiencia de viejo soldado, el erudito capellán no hace sino leer una voluntad divina para la cual cualquier testimonio surgido desde abajo ha de resultar insustancial, pues el Altísimo al fin y al cabo solo «quiere que se escriban las guerras, hechos y vidas de reyes y capitanes» (López de Gómara 2000a: 39). Resulta lógico que Gómara, para hablar de Hernán Cortés e inscribir sus hazañas entre las historias del mundo, no pueda dejar de ir - enseguida lo veremos - de los asirios, los medos y los persas a los visigodos, y de estos a su presente. Como hace ya muchas décadas nos explicase magistralmente Auerbach (1996: 75-76), la exégesis figural establece una relación entre dos acontecimientos o personas en la cual el primer actor tiene su significación propia al tiempo que apunta al otro. El proceso, a la inversa, también goza de pleno sentido: Cortés asume, pongamos por caso, la figura de Alejandro y la consuma con sus hazañas. Que los dos polos de la comparación estén separados en el tiempo y sin embargo en ligazón no es ilógico, pues en las categorías temporales que maneja Gómara, que no son las nuestras, aunque a veces nos lo puedan parecer, se sigue dando una relación entre un polo y otro 
de la figura. Cuestión distinta es que convenga establecer de partida cuáles son esas categorías concretas a que nos referimos 9 .

Consideremos que el concepto de tiempo que maneja López de Gómara se nos presenta estratificado en una articulación dual de la historia dentro de la cual hay un tiempo eterno, la aeternitas, atributo exclusivo de Dios, tiempo estacionario que carece de principio y de final, y un tiempo terrenal, el tempus, en cuyo interior se explica toda modificación en tanto tiempo de los seres corporales que recorren cada cual un ciclo con principio, final y modificación. Toda historia, para las mentalidades sacralizadas, está comprendida dentro de la aeternitas, como en todas las historias, caso concreto de la de Cortés, se percibe el efecto del tempus. Ahora bien, desde el Medievo se había establecido una tercera categoría, intermedia, para explicar la existencia de los seres que tienen un principio y un final, pero cuyos cambios no afectan a su sustancia: el aevum. En ese sentido puede decirse que la historia de Cortés, tal como la presenta Gómara, existe en aevum desde el momento en que queda inscrita entre las historias del mundo, pues es posible apreciar en ella los cambios del devenir terrenal, a cuyos azares no deja de estar sujeta la hacienda, al mismo tiempo que la sustancia de la honra se mantiene inmutable, prolongándose por encima de toda contingencia. Así se explica ese hilo de continuidad histórica entre elementos para nosotros dispares (no para Gómara, desde luego) que fluctúa sobre las circunstancias en su narración ya desde el principio:

Se acabaron los reinos y linajes de Nino, Darío y Ciro, que comenzaron los imperios de asirios, medos y persas; mas duran sus nombres y famas en las historias. Los reyes godos de nuestra España murieron con Rodrigo, pero sus gloriosos hechos viven en las crónicas (López de Gómara 2000a: 39).

Lo que viene a ser, poco más o menos, lo contrario de lo que les sucede a los seres que solo viven en el tempus, volubles y sujetos a toda alteración, como podemos constatar en un breve apunte antisemita de nuestro capellán: «No deberíamos meter en esta cuenta a los reyes de los judíos, cuyas vidas y mudanzas contienen grandes misterios; sin embargo, no permanecieron mucho en el estado de David, varón según el corazón de Dios» (ibíd.).

Si en la vieja exégesis figural el Antiguo Testamento es la prefiguración del Nuevo, unidos ambos verticalmente a través de la Providencia Divina, en la visión de Gómara la historia es aquello que actualiza los grandes hechos de los antepasados en el presente de Cortés, en ligazón lógica. Con todo, la dedicatoria a Martín Cortés no deja de ser una alabanza y una advertencia, pues ya hemos señalado cómo nuestro capellán previene a su mecenas sobre las contingencias de la hacienda. Dios conoce las causas de nuestros actos — nostras

9 Para la diferencia entre aeternitas, tempus y aevum que expondremos a continuación, véase el trabajo fundamental de Pomian (1990: 62-64). 
voluntates ignorare non potuit, escribe San Agustín (2004: 314) en De Civitate Dei $(\mathrm{V}, 9)$ - , de lo que concluimos que para Dios está determinado el orden de las causas, sin que de ello se colija la negación del libre albedrío. Las voluntades humanas, desde esta perspectiva, pertenecen al orden de las causas conocidas de antemano por Dios, y quien conoce el orden de las causas de los acontecimientos ni ignora dichas voluntades ni ignora las causas de los actos que de ellas se derivan. Determinar qué procedimientos técnicos guiaron la labor de Gómara a la hora de dar soporte en su Historia a este sustrato enunciativo ya es harina de otro costal.

\section{De Gómara a Bernal: un hilo y muchos nudos}

\subsection{Primer nudo: un «testigo jurado» y un «testigo de vista»}

Recientes investigaciones han puesto de manifiesto algunos equívocos respecto a la figura de López de Gómara y su relación con la casa de los marqueses del Valle de Oaxaca. Entre estas, sin duda ha de contarse un trabajo más que destacable de Martínez Martínez (2010), quien pone algunos puntos sobre las íes que no podemos ignorar aquí. Aunque se ha dado por supuesta la relación de Gómara con Hernán Cortés, y aunque es más que probable que esta existiese, lo cierto es que no hay constancia documental de ella más allá del vínculo — este sí, muy probado - del capellán con Martín Cortés. Asimismo, se ha creído siempre que Gómara habría entrado en contacto con Cortés durante el sitio de Argel en 1541, pero lo cierto es que él mismo declara conocerlo desde la primera vez que el conquistador vino a España, habiéndose tenido que producir el encuentro por primera vez en 1529 o 1530. Tampoco es menos relevante recordar que, a pesar de que tal es la condición que le atribuye Bartolomé de Las Casas cuando alude a él, no parece probable siquiera que Gómara fuese confesor de Cortés, como siempre se ha creído. De hecho, si bien se intuye que Gómara parece conocer al conquistador y tener cierto trato con él, la relación de amistad solo es declarada recíprocamente en el caso de Martín Cortés. Todo esto, más o menos secundario, habrá que matizarlo en el futuro, pero lo que sí sabemos con certeza es que Gómara fue testigo en sendos pleitos de la familia a propósito de la boda de María Cortés y que como tal es citado en 1549 durante un litigio de los marqueses del Valle contra el marqués de Astorga.

De todo lo cual concluimos un hecho que a la postre será decisivo: respecto a las cosas de Cortés, Francisco López de Gómara es un «testigo jurado», un hombre de papeles, y la diferencia con lo que va a representar Bernal Díaz del Castillo no puede considerarse menor en este punto. Este hablará, como Gómara, sobre la historia de Cortés, pero no ya en calidad de «testigo jurado» sino de «testigo de vista», lo cual es algo bien diferente. 
El método de trabajo de Gómara, por otra parte, tampoco es algo en lo que debamos dejar de indagar. Recordemos que Hernán Cortés había muerto en 1547, y que para escribir su Historia Gómara se había visto obligado a recabar información directamente de algunos de los allegados del conquistador, sin que esté claro en absoluto, como acabamos de señalar, que la hubiese obtenido de su trato directo con él. No en vano, fue este proceder de compilador de documentos el que llevó en su día a Simón Valcárcel Martínez a considerar a Gómara como figura contradictoria a medio camino entre la Edad Media y el Renacimiento. Por una parte, recuerda, hay una oscilación en su criterio de autoridad que a este investigador le parece moderna:

El criterio de autoridad que sigue Gómara oscila entre lo escrito por los autores de la Antigüedad greco-latina y la experiencia obtenida por sus contemporáneos (y, en la mayoría de las ocasiones, compatriotas españoles) en el descubrimiento y colonización de las Indias, que es el tema que Gómara historia (Valcárcel Martínez 1989: 14).

Por otra, no deja de señalar entre «ciertas adherencias medievales», al margen del ya señalado providencialismo, «también la excesiva autoridad concedida a la Biblia» (ibíd.: 18). Por nuestra parte, a pesar de lo que hemos dicho de la escritura como glosa de la Escritura, nos vemos obligados a matizar que nuestra posición a este respecto será distinta.

Y lo será porque no creemos que Edad Media o Renacimiento constituyan per se categorías preexistentes al objeto de nuestro estudio o al propio Gómara. Es cierto que el autor de La conquista de México se guía por un criterio que podríamos calificar de humanista; es cierto, incluso, que a veces se permite ironizar sobre la «sabia antigüedad» que, no obstante, había sido incapaz de cruzar el Atlántico, pero la lógica por la que se rige Gómara es ante todo la propia del cronista no del todo ajeno a las categorías de la sacralización feudal tardía. Insistamos en que el cronista de Cortés es ante todo un hombre de libros, lo que en este contexto equivale a decir que es un hombre sometido a la auctoritas de los libros. En uno de sus inéditos, recogido hace ahora tres lustros bajo el título de Guerras de mar del emperador Carlos $V$, escribe acerca del asombro que le produce el trato con marinos mientras trata de documentar el arte de la navegación. A Gómara parece fascinarle «que tan sutil arte y tan usada y peligrosa esté en gente grosera y que no sabe leer» (López de Gómara 2000b: 58).

Solo que Bernal sí sabe leer, y es aquí donde por contraste nos topamos, nosotros y Gómara, por vez primera con un problema crucial: leer ya no es necesariamente el reconocimiento hasta el infinito de los trazos de la auctoritas. No negamos que Manuel Durán tenga razón cuando presenta a Bernal como un autor poco leído; es posible incluso que no sea en absoluto descabellado suscribir con él que «casi sería imposible hallar en el Renacimiento español, 
con la excepción de Santa Teresa, un autor menos pedante y más libre de influencias literarias que Bernal Díaz» (Durán 1992: 796). Pero de que Bernal había leído cuando menos lo imprescindible, es decir, a Gómara y al mundo que había visto con sus propios ojos, no cabe la menor duda. Tampoco de que iba a saber hacer de la necesidad virtud.

\subsection{Segundo nudo: excusatio propter infirmitatem}

La recurrencia al tópico de la falsa modestia sirve para establecer una oposición entre Bernal y los cronistas doctos. Coadyuva a ello el que tantas veces asome la cabeza por el texto la imagen del escritor como viejo soldado que se supone iletrado. Ya en el preámbulo del manuscrito G, Díaz del Castillo (2011: 3) alude a cómo algunos «afamados coronistas, antes que comiencen a escrebir sus historias, hacen primero su prólogo y preámbulo con razones y retórica muy subida», a diferencia de él, que solo puede optar por una posición necesariamente antirretórica: «Y yo, como no soy latino, no me atrevo a hacer preámbulo ni prólogo dello» (ibíd.: 4$)^{10}$. El preámbulo al manuscrito A es todavía más explícito del motivo retórico de la excusatio propter infirmitatem, pues como dice Green (1983: 648): «A manera de prólogo, Bernal se niega a escribir un prólogo». Escribe Bernal:

Hanme preguntado ciertos caballeros y curiosos letores que por qué no hago prólogo en esta mi primera parte sobre los hechos del valeroso y esforzado capitán don Hernando Cortés, marqués del valle, pues hay mucha razón que lo hiciese. A esto se puede responder, y digo ahora, que es menester, para podello decir y esplicar tan subida y altamente como merece, un muy afamado coronista que tuviese gran elocuencia y agraciada retórica, que supiese dar comienzo, medio y fin en su alabanza, porque si bien se nota, no hallaremos escrito de nuestros tiempos más heroicas hazañas, tan estimadas y de tanta ventura como las que hizo este tan estimado y nombrado Marqués. E a esta causa no me atrevo a escrebillo, porque no sabré ni alcanzará mi poco saber meter la mano en tan sublimados hechos y cosas de espanto, que no son de creer si no se hobiesen visto por los ojos (Díaz del Castillo 2011: 6-7).

${ }^{10}$ Será una estrategia relativamente frecuente. Recuérdese el Capítulo CCXII, donde Bernal cuenta lo que le ocurre tras poner en limpio su relación: «me rogaron dos licenciados que se la emprestase por dos días para saber muy por extenso las cosas que pasamos en la conquista de México y Nueva España y ver en qué diferían lo que tienen escrito los coronistas de Gómara y el dotor Illescas cerca de los heroicos hechos y hazañas que hecimos en compañía del valeroso marqués Cortés; e yo les presté un borrador. Pareciome que de varones sabios siempre se pega algo a los sin letras como yo soy» (Díaz del Castillo 2011: 10661068). Para Brody (1987: 325) habría que leer el sentido de las expresiones de modestia de Bernal en clave irónica a partir del Capítulo XVI, cuando comienza a confrontarse con Gómara, mientras que antes — según él - resultarían sinceras. Una vez más, en cualquier caso, podríamos hablar de una reducción de un problema ideológico fundamental al psicologismo. 
De modo que ahí tenemos al Bernal «testigo de vista» que se reivindica sutilmente como tal frente al «testigo jurado» que es Gómara. Uno ve a través de la escritura y el testimonio ajeno, el otro por los ojos.

$\mathrm{Y}$ es en esa reivindicación donde hay que buscar, sin lugar a duda, una de las claves más perentorias de su escritura, pues de ella surgirá la modernidad que queremos señalarle con este trabajo. En los preámbulos editados por Serés constatamos que Díaz del Castillo no pierde oportunidad de subrayar el contraste entre los finos retóricos y él mismo. Así en el de $\mathrm{G}$, donde rebaja su escritura a la condición de sermo humilis al tiempo que se declara «testigo de vista», cosa que a la postre será fundamental:

Y para podello escrebir tan sublimadamente como es dino, fuera menester otra elocuencia y retórica mejor que no la mía; mas lo que yo vi y me hallé en ello peleando, como buen testigo de vista, yo lo escrebiré, con el ayuda de Dios, muy llanamente, sin torcer a una parte ni a otra (2011: 4).

Y así en el de A:

Y esta historia dará relación dello, de lo que vi yo siendo un su compañero y soldado: me hallé juntamente con él batallando en lo que arriba dicho tengo, y es de comparar la mar con los arroyos. Y por no gastar razones, digo que no me atreví a ello más de hacer este argumento y relación (2011: 7).

Aunque se ha observado que este último texto puede estar enmendado por el hijo de Bernal, Francisco Díaz, lo que dice ni es menos importante ni desentona en lo más mínimo con la tónica de que lo que se escribe no es alta retórica sino una mera relación. Una relación motivada, al fin y al cabo, por su orgullo de soldado (compañero y soldado, para ser exactos).

Esta oposición entre altos retóricos y el idiota sin letras, pues tal dice en algún momento ser Bernal, ha sido abordada de diversas maneras por la crítica, aunque en general pensamos que se pueden señalar dos grandes vertientes en su exégesis. Por una parte, existe una línea interpretativa que busca abordar desde el psicologismo la retórica de nuestro autor: así, la respuesta de Díaz del Castillo ante la escritura de Gómara no dejaría de ser un efecto de la irritación que se supone sentiría Bernal al darse cuenta de cómo historiadores profesionales al modo de Gómara disfrutaban del prestigio y la autoridad moral que a él le estaban vedadas, de manera que su mejor argumento descansaría «on the distinction between the modalities de re and de dicto, that is, a kind of "natural truth" of the deeds and a "moral truth" of their narration» (Adorno 1992: 217) ${ }^{11}$;

${ }^{11}$ La misma autora había explicado en otra parte que «when Bernal harangued against Gómara and others for not having been present at the conquest, his real complaint was not that they could not "get their facts straight", bur that they could not share the conquistors' point of view nor write about them in a appropiately sympathetic manner. That is why, in 
antes, ya Brody (1987: 333) se había esforzado por establecer cómo más que en el intento de sustituir una versión de la historia por otra, «Bernal's major point was that the role played by the common soldier in the conquest had been overlooked, and it was incumbent upon him (Bernal) to fill in the void, to show that the common soldier was as much a conquistador as Cortés». Por otra parte, apreciamos una segunda línea de investigación que tiende a atribuirle un cierto retoricismo a Díaz del Castillo: ha sido señalado que los cronistas de su misma cuerda «oponían verdad recta en la narración de los hechos, a buena retórica, policía, elocuencia, ornato encumbrado, estilo delicado, cualidades todas de la literatura pero no de la realidad vivida y sufrida» (Caillet-Bois 1960: 221); Romero (1988: 338) directamente cree que para hacer valer su Historia, «Bernal establecerá la oposición verdad (suya) vs. retórica (de Gómara)»; y para Durán (1992: 795):

López de Gómara representa la historia vista desde la atalaya aristocrática, la historia de los héroes, de los príncipes, de los monarcas, la historia creada por la nobleza. Bernal Díaz, al contrario, representa la visión populista de la historia: son los humildes soldados, como él, los que fraguan la victoria.

De modo que Gómara devendría el artífice de un modo aristocrático de hacer historia, especificará Durán, cuyo paradigma sería Plutarco, quien elige la versión de los hechos que resulta más favorable a los nobles teniendo en cuenta que los grandes vicios, como las grandes virtudes, son cosa de almas grandes, mientras que Bernal representaría el modo populista paradigmático de Jenofonte, de acuerdo con el cual solo quedaría plasmado el punto de vista biográfico de un personaje a la defensiva ${ }^{12}$.

Pero volvamos al comienzo de la primera versión impresa, la de 1632. La ahí titulada Declaración del Autor no parece ser otra cosa que eso, una declaración en carta enviada al Consejo de Indias, como muestra la redacción de una conclusión marcada por un estilo más o menos notarial ${ }^{13}$. Por ello puede dar la impresión de que se trata de un texto que no conviene ser tomado muy en serio, aunque si indagamos en él tal vez se acabe revelando de capital impor-

\footnotetext{
Bernal's view, they presented accounts — be they accurate or inaccurate in detail- which missed the mark ("no aciertan") because their narratives did not capture the perspective, or therefore reflect the interests, of the veterans who had fought the war» (Adorno 1988: 245).

12 No obstante, Durán (1992: 796) señala: «aunque la Anábasis de Jenofonte fue traducida al castellano por Diego Gracián y publicada en Salamanca en 1552, y por tanto durante la vida de Bernal Díaz, las probabilidades de que esta versión le fuera conocida son muy remotas».

13 O sea: «Tengo de acabar de escriuir ciertas cosas que faltan que aun no se han acabado: va en muchas partes testado, lo qual no se ha de leer. Pido merced a los señores Impressores, que no quiten ni añadan mas letras de las que aqui van, e suplan, etc.» (Díaz del Castillo 1632: fol. 12).
} 
tancia. En esa especie de prólogo dudoso o falso preámbulo, a diferencia de los manuscritos $\mathrm{G}$ y A, Bernal no gasta demasiadas razones retóricas en la contraposición con Gómara y sus seguidores, sino que se les opone frontalmente cuando escribe:

È tambien van declarados los borrones, è cosas escritas viciosas, en vn libro de Francisco Lopez de Gomara, que no solamente va errado en lo que escriuio de la Nueua España, sino que tambien hizo errar a dos famosos Historiadores que siguieron su Historia, que se dizen el Doctor Illescas, y el Obispo Paulo Iobio; y a esta causa digo e afirmo, que lo que en este libro se contiene, va mui verdadero, que como testigo de vista me hallè en todas las batallas è rencuentros de guerra: è no son cuentos viejos, ni Historias de Romanos de más de setecientos años, porque a manera de dezir ayer passò lo que veran en mi Historia (Díaz del Castillo 1632: fol. 12).

Es obvio que la Historia verdadera se ha visto lastrada por la de Gómara cuando llega por primera vez al Consejo de Indias. Ya hemos dicho que frente al «testigo jurado» de la familia de los Cortés que es Gómara, Bernal siempre será «testigo de vista» de los hechos, cosa de la que nos ocuparemos enseguida, no sin antes insistir en esa frase impresionante por la que nuestro veterano soldado asegura que lo que él escribe no son cuentos viejos, ni Historias de Romanos de más de setecientos años. La valoración temporal que conlleva no es gratuita: si lo que él relata no es una Historia de más de setecientos años, ello se debe a que ayer pasó lo que se leerá en las páginas que han de seguir. Pura tautología, pero esto lo escribe no antes de 1568 un Bernal Díaz del Castillo ya anciano. Bien es cierto que la primera edición de La conquista de México de López de Gómara es de 1552, pero sus seguidores, a los que alude nuestro soldado, se tomarían algo más de tiempo en leerlo. Gonzalo de Illescas había publicado su Historia pontificial en 1565 y la Segunda parte de la Historia Pontificial en ese mismo año. Por su parte, Paolo Giovio (llamado en España Paulo Jovio) había escrito sendas obras en italiano y latín con los títulos respectivos de Vite brevemente scritte d'huomini illustri di guerra (1560) e Historiarum sui temporis ab a. 1494 ad a. 1547 (1550-1552). Las traducciones al castellano no se hicieron esperar mucho pero sí algo: en 1566 se pone en dicha lengua la última como Segunda parte de la historia general de todas las cosas (1566), mientras que la primera, bajo el título de Elogios o vidas de los caballeros antiguos y modernos, ilustres en valor de guerra, es traducida por Gaspar de Baeza en 1568. De modo que no otro que 1568 es el año límite que ha de fijarse para la reacción definitiva que provocaría en Bernal el conocimiento de las obras de Gómara y de sus seguidores. La cuestión ahora no puede ser otra: ¿cómo y por qué había empezado todo? 


\subsection{Tercer nudo: del memorial de méritos a la Historia verdadera}

Así pues, sabemos que Bernal envía al Consejo de Indias el manuscrito $\mathrm{G}$ en 1568, pero también que nunca dejaría de seguir corrigiendo el texto de su relación, en un proceso por el cual esta, haciéndose cada vez más compleja, se va poco a poco deslizando desde su primera concepción como memorial de méritos hacia esa otra cosa tan difícil de definir que es hoy la Historia verdadera. Porque, en efecto, a la luz de la documentación conservada nos parece de todo punto insoslayable que, en una fase intermedia de redacción, la obra fue un memorial de méritos motivado por la necesidad. Una necesidad, ha indicado Guillermo Serés, que se comprende mejor si nos remontamos a 1526, año en que Bernal Díaz del Castillo es desposeído de ciertos pueblos que se le habían dado en encomienda:

A partir de ese momento su vida se convirtió en una constante demanda de alegatos, peticiones y probanzas de méritos y servicios, por los que exigía se le reconociesen sus gestas y curriculum de «viejo conquistador» que le permitieran conservar sus privilegios y, obviamente, su encomienda de indios, su principal fortuna (Serés 2011a: 1123-1124).

Algunos de esos documentos menores que de un modo u otro están relacionados con la génesis de la Historia verdadera de la conquista de la Nueva España se han conservado ${ }^{14}$, y entre ellos hay dos que nos parecen de la mayor relevancia.

Uno es la carta a Carlos V con fecha de 22 de febrero de 1552, en la que se queja Bernal del trato que le dispensa el presidente de la Audiencia de Guatemala, a la sazón Alonso López de Cerrato. La crítica ha señalado que en esa carta nuestro autor ya deja entrever un cierto concepto de sí mismo caracterizado por la excesiva importancia que concede a su figura: «Bien creo que se terná notiçia de mí en ese vuestro Real Consejo de Yndia, y commo e servido á V. M. desde que era bien manzebo asta agora que estoy en senetud» (Díaz del Castillo 1877a: 38). Puede ser, pero quizá tampoco convenga perder de vista que la estrategia de exagerar la propia valía no es sino un recurso retórico — por lo demás, muy común - pensado para tratar de granjearse algo de atención en mitad de la maraña burocrática de la administración de las Indias. Lo que desde luego no será ajeno a la Historia verdadera es el orgullo de viejo soldado que se va trasluciendo ahí, como tampoco que tras el relato de sus desavenencias con Cerrato leamos ni más ni menos que lo siguiente: «y biendo esto, atrebo me azer esta relaçion» (Díaz del Castillo 1877a: 39). Que la carta de Bernal no obtuviese respuesta, como en efecto no la obtuvo, hace que paradójicamente deba ser considerada hoy un documento clave, pues nos

${ }^{14}$ Véase la relación que en su día ya ofreció Wagner (1945). 
permite deducir que a raíz de este silencio se sentiría Bernal espoleado para emprender al año siguiente la redacción de la Historia verdadera, o al menos del memorial de méritos que suscribimos fue su principio.

El otro documento que nos interesa es una segunda carta, ya dirigida a Felipe II, datada el 20 de febrero de 1558. Como la anterior, esta trata también sobre la encomienda de indios, pero he aquí que entre petición y petición encontramos esto:

Y quiero dar cuenta de quien soy para que V. M. más cumplidas merçedes sea servido azerme. Yo soy hijo de Françisco Diaz el Galan, vuestro regidor que fué de Medina del Canpo, que aya santa gloria, é soy en esta çivdad vuestro regidor, é al presente vuestro fiel é executor por vuestra Real Avdençia é por botos del cabildo; é soy devdo bien çercano de vuestro oydor que fué, que aya santa gloria, el liçençiado Gutierre Belazquez, é e servido á V. M. en estas partes de quarenta años á esta parte, porque me allé en el descobrir é conquistas de Mexico con el marques del Valle: lo qual antes de agora costa en vuestro Real Consejo de Yndias, y lo sabe bien Don frey Bartolomé de las Casas, obispo que fué de Chiapa. Agora torno á suplicar de nuevo sea servido de me azer merçed de la fyel ysecutoria desta tierra, digo desta çivdad; pues soy tan biejo criado de V. C. y R. M. y de mi padre é devdos sienpre le an servido, é en ello reçebiré muy señaladas merçedes. Nuestro Señor Jesuchristo dé á V. C. y R. M. muchos años de vida, con mucha salud, con avmentaçión de más reynos, ansy commo V. R. M. desea é yo su leal criado querria, que bien se puede fiar de mí. E de Guatimala xx de hebrero de MDLviij años (Díaz del Castillo 1877b: 47).

Una vez más estamos ante un artificio burocrático al uso, pero no solo, pues aplicando la sentencia de manera un tanto espuria, ese quiero dar cuenta de quién soy con el que empieza la cita anterior muy bien pudiera ser la clave definitoria de la escritura de la Historia verdadera. Hay algo en ese proceder que cae dentro de lo convencional, pero también algo que lo rebasa. Pura convención es, desde luego, empezar aludiendo desde una remota vejez al origen castellano para enfatizar la importancia de una vida puesta al servicio de la corona mediante el ejercicio de las armas. Tampoco en la Historia verdadera esta necesaria alusión a los orígenes está del todo ausente, si nos atenemos al preámbulo de G:

Y porque soy viejo de más de ochenta y cuatro años y he perdido la vista y el oír, y por mi ventura no tengo otra riqueza que dejar a mis hijos y decendientes salvo esta mi verdadera y notable relación, como adelante en ella verán, no tocaré por agora en más decir y dar razón de mi patria y dónde soy natural y qué año salí de Castilla y en compañía de qué capitanes andube militando y dónde agora tengo mi asiento y vivienda (Díaz del Castillo 2011: 4).

Pero también es cierto que se trata de una convención de la que ni mucho menos dudará en valerse López de Gómara en su relato cronístico a mayor gloria de Cortés: 
El año 1458, siendo reyes de Castilla y Aragón los católicos don Fernando y doña Isabel, nació Hernán Cortés en Medellín. Su padre se llamó Martín Cortés de Monroy, y su madre doña Catalina Pizarro Altamirano: entrambos eran hidalgos, pues todos estos cuatro linajes, Cortés, Monroy, Pizarro y Altamirano, son muy antiguos, nobles y honrados. Tenían poca hacienda, empero mucha honra, lo cual raras veces acontece si no es en personas de buena vida (López de Gómara 2000a: 41).

Lo que tiene de rebasamiento de la convención el texto de Bernal no se aprecia tanto por la estrategia retórica en sí cuanto por la presencia de otro detalle bastante más sutil que trataremos de explicar a continuación.

Nada de particular tiene que la hazaña de Cortés fuese narrada por Gómara como desplazamiento desde unos orígenes más o menos humildes — poca hacienda, empero mucha honra - hasta el logro del más honroso de los estados; movimiento, por lo demás, poco menos que inevitable desde los parámetros ideológicos en los que está inserto el cronista. Como en las figuras de los libros de caballerías o las de las crónicas, todo movimiento perfecto, incluido el social, se define por su circularidad y su tendencia al reposo: circularidad en tanto Cortés, al igual que el caballero o el santo, nunca sale de la honrosa posición que la naturaleza le ha dado por la vía del linaje, limitándose si acaso a confirmarla y acrecentarla, pues será a causa de la mucha honra como verá el conquistador remedada su poca hacienda; y tendencia al reposo porque el reposo es, Aristóteles mediante, el estado al que tiende aquello que busca alcanzar su lugar natural, tal cual esa gesta y ese nombre fijados para los restos, como decíamos antes, entre las historias del mundo.

Por su parte, el caso de Bernal no dista tanto quizá de ese otro del yo que recurre a los orígenes para contarse a sí mismo desde abajo, como sucede con el Lazarillo, el Guzmán de Alfarache o El Buscón ${ }^{15}$. Si Bernal está emparentado con Cortés no solo lo está a causa de su origen hidalgo (recordemos que es hijo de un regidor de Medina del Campo), sino en virtud del valor que parece conceder a su propio mérito en el relato que construye ${ }^{16}$. Un relato que, así considerado, es ascendente en dos sentidos: en tanto parece haber sido conce-

15 Es cierto que, como ha mostrado Juan Carlos Rodríguez (2001), en el caso de la enunciación de cualquiera de esas tres obras cabría hablar de la irrupción de la pobreza y su enunciación literaria, algo que no parece casar en absoluto con la atmósfera de la Historia verdadera, pero en ese mismo ensayo aborda Rodríguez un hecho decisivo que sí es aplicable a Bernal Díaz del Castillo, y es que, frente a la hagiografía medieval, esa lógica enunciativa que tiende a privilegiar la narración de una vida contada desde abajo implica en todo momento la aparición de la mirada literal: «La mirada literal supone aceptar las apariencias tal como se ven, la relación ojo/cosa y, por tanto, la anulación de la multiplicidad de sentidos propia de la lectura feudal» (Rodríguez 2001: 45-46).

16 Imposible no recordar aquí la famosa sentencia del Lazarillo: «y también porque consideren los que heredaron nobles estados cuán poco se les debe, pues Fortuna fue con ellos parcial, y cuánto más hicieron los que, siéndoles contraria, con fuerza y maña reman- 
bido, en primera instancia, para el medro social; y en tanto, sobre todo, delata la presencia enunciativa de ese nuevo yo que está apareciendo y que se narra a sí mismo ya no de manera circular, como en la hagiografía o el libro de caballerías, sino desde abajo. Por ello, que Bernal insista en declararse a sí mismo «testigo de vista», más allá de reforzar la tesis del origen como memorial de méritos de la Historia verdadera, lo sitúa en el punto de vista de la mirada literal frente a cualquier pretensión alegorizante.

Sea como fuere, hemos llegado hasta un memorial de méritos - porque sin duda se trata de eso, de «un memorial de méritos genial», a decir de Ángel Valbuena Briones (1958: 87) — que con mucho desborda todas las convenciones que le serían inherentes en tanto tal. Se ha escrito que en la Historia verdadera la «referencia constante al carácter de "visto y vivido" con relación a la materia narrada se va a convertir en un hecho casi formulaico» (Romero 1988: 339), lo cual es cierto, pero será en virtud de ese procedimiento casi formulaico, con todo lo que ello implica, como el documento burocrático que es en origen la obra de Bernal se amplíe hasta llegar a convertirse en otra cosa. Nótese que así se demuestra en diversos pasajes, como el famoso Capítulo CCXII —el de los dos licenciados - que da pie a Bernal a insistir en que no quita ni añade una coma: «porque todo lo que escribo es muy verdadero» (Díaz del Castillo 2011: 1068). Procede así marcando bien las distancias con Gómara y sus seguidores: "Y estos que escrebieron es que ni se hallaron presentes en la Nueva España; y sin tener verdadera relación ¿cómo lo podían escrebir sino a sabor de su paladar, sin ir errados, salvo que en las pláticas que tomaron del mesmo marqués?» (1074).

No son chicas las diferencias. Bernal, frente a los que hablan con Cortés y su entorno, habla de lo que él mismo ve, como frente a los que escriben una Historia, escribe una Historia verdadera, cosa — su adjetivación como verdadera- que conviene tomarse muy en serio, porque hay un nuevo yo, una nueva forma de enunciación, que estamos viendo cómo empieza ya a asomar la cabeza ahí.

\subsection{Cuarto nudo: la enunciación del yo moderno}

Empezamos este trabajo señalando cómo algunos libros recientes optan por un desplazamiento hacia la lectura novelesca o literaria del texto. El encaje ahí del yo de Bernal parece desenvolverse dentro de las dos líneas, empirista y psicologista, que precisamente Oswaldo Estrada y Verónica Cortínez representan de manera respectiva. Así, para el primero la enunciación de la escritura de Díaz del Castillo está imbuida de una suerte de empirismo:

do salieron a buen puerto» (Lazarillo 2011: 5). Para la noción de mérito, véase una vez más Juan Carlos Rodríguez (1990: 31-58). 
Pese a que Bernal reconoce no escribir como un hombre que ha pasado por la universidad (como su capitán Cortés, por ejemplo, o Gómara, a quien contradice a lo largo de su crónica), desde su prólogo autoriza el contenido de su discurso con el sello de su experiencia: «lo que vi y me hallé en ello peleando, como buen testigo de vista yo lo escribiré, con la ayuda de Dios, muy llanamente» (XXXV). Aun cuando fuera cierto, según lo demuestran estudios recientes, que no es Bernal sino su hijo Francisco quien escribe este prólogo después de la muerte de su padre en Guatemala, en toda la crítica bernaldiana prima el valor de lo vivido y las acciones individuales que surgen en plena acción (Estrada 2009: 40).

Por nuestra parte, pensamos que Estrada en absoluto yerra al valerse del verbo autorizar para definir el papel que desempeñan tanto el sello de la experiencia como el valor de lo vivido y las acciones individuales en el discurso de Bernal, aunque sí trataremos de matizar esa posición un poco más.

No sin antes señalar cómo en esta misma línea empirista se sitúa el trabajo de Mario Rodríguez Fernández, quien tras intentar encuadrar a nuestro autor en su óptica histórica, el Renacimiento, lo muestra rechazando toda la historiografía de su época, basada tanto en el criterio libresco como en el de autoridad, a decir de este investigador, quien afirma sobre Bernal que «la realidad histórica reside para él en el hecho individual y concreto, allí, en la plenitud de lo empírico y lo específico, se despliega lo real, la sustancia cierta del acaecer» (Rodríguez Fernández 1966: 23). O sea, que el hecho individual y concreto del que se despliega lo real exige a Bernal ser testigo de vista, aunque quizá podamos preguntarnos si no lo estamos convirtiendo en un filósofo más complejo de lo que él mismo se pretendió. Para Antonio Romero (1988: 343), en cambio, Bernal es un historiador que denuncia la «falacia antirretórica»:

Las técnicas que utiliza este sistema de acercamiento al lector son técnicas dramatizadoras, en las que predomina el mostrar (showing) frente al relatar (telling). El sentido que estas técnicas narrativas adquieren en la obra de Bernal Díaz es el de apoyar la veracidad por medio de la actualización, y lo hacen de manera muy semejante a la de las técnicas propias del discurso historiográfico (los shifters de organización, el tiempo presente del historiador).

Guillermo Turner (1993: 22), por su parte, incide en este criterio que «consiste, nada menos, que en haber estado presente en dichos sucesos, es decir, haberlos visto».

Sin alejarse del todo de la tesis empirista, algunos de los trabajos de Verónica Cortínez sí parecen escorarse también hacia cierto psicologismo cuyo eje central sería, según ya vimos, la frustración de Bernal por no poder recuperar íntegramente su pasado:

La frustración de Bernal culmina cuando los dos licenciados a quienes les ha prestado un borrador de todo el texto le critican la falta de testigos. ¿Cómo pretende dar crédito a sus palabras si no tiene a nadie que las atestigüe? Su propó- 
sito inicial de contar toda la verdad recuperando los detalles del pasado queda, por lo tanto, frustrado. El tratarse de la memoria de un solo narrador impide la reconstrucción íntegra del pasado. Lo que él no recuerda, y por consiguiente, no escribe, está condenado al silencio. Más aún, la imposibilidad de Bernal, como de todo narrador en primera persona, de incluirse, objetivamente, dentro de su testimonio, cuestiona la veracidad de lo narrado. Bernal, consciente del contrasentido que se le exige, aclara: «porque yo no soy testigo de mí mismo.... ¿por qué no lo diré? Y aún con letras de oro había de estar escrito. ¿Quisieran que lo digan las nubes o los pájaros que en aquellos tiempos pasaron por alto?» (Cortínez 1991: 322-323).

Si el relato de Bernal no es entonces otra cosa en última instancia que el relato de una frustración - la que le produce al autor el no poder recuperar el pasado-, el camino hacia su homologación con una especie de sujeto escindido al estilo romántico antes del Romanticismo, hacia ser considerado una puesta en jaque del yo moderno antes de la consolidación definitiva del propio yo moderno, queda despejado. Poco más tarde insistirá Cortínez (1993: 63) en que «Bernal se entromete en la historia que cuenta para hacernos partícipes de una problemática ajena a la conquista: cómo recuperar íntegramente el pasado $\mathrm{y}$, sobre todo, cómo plasmarlo en palabras». Nosotros diríamos que demasiado ajena, la verdad, pero para Cortínez dicha problemática parece ser la que lo envuelve todo en la Historia verdadera. En la medida en que la exégesis se desplaza hacia el psicologismo, la suposición de que el perspectivismo moderno está también enunciando la narrativa de Bernal se hace más explícita: «Lo verdaderamente "notable y digno" de la Historia verdadera es la incapacidad del narrador de mantenerse fiel a una sola perspectiva. A pesar suyo, Bernal Díaz comprueba que es necesario ajustar la realidad vivida a las exigencias de la escritura» (Cortínez 1993: 66). Por ese camino es como llegará esta autora a la gran reivindicación literaria de Bernal que, según señalábamos al principio, supone su monografía (Cortínez 2000).

En todo caso, Cortínez no es ni mucho menos la única autora que opta por la interpretación psicologista. Se ha escrito que «Bernal reviews the interior of his memories and he decides to justify himself before others. The instrument for his justification is made up of his own written words, as opposed to the words of the scribe / notary during an earlier probanza de méritos» (Angulo-Cano 2010: 292). A lo que Angulo-Cano (2010: 293) añade que «the self-justificacion project may well be the first result of the writer's introspective reflection for giving coherence and meaning to his life». Su tesis postula que Bernal busca dotar de coherencia y sentido a su vida, situándose en el tránsito de una sociedad de guerreros patriarcal —y así lo mostraría la carta a Felipe II antes citada - hacia la forja de un yo individual e introspectivo.

No cruzaremos nosotros esas procelosas aguas de las explicaciones psicológicas, pero eso no significa en absoluto que el yo que está enunciando - $-\mathrm{y}$ aun enunciándose - en la Historia verdadera no merezca ser considerado con 
el mayor de los cuidados, o que no pueda estudiarse como un nuevo elemento histórico que rompe con la lógica enunciativa anterior. Guillermo Serés (2004: 27), sin duda uno de los mejores conocedores de la obra bernaldiana, propone una lectura del título mediante la cual habría que poner en relación la palabra Historia con la voz griega istorien, que significa «ver», de modo que los historiadores serían «los que ven», los testigos de vista; luego — añadirá Serésel sintagma se vuelve pleonástico al hablar de Historia verdadera (ibíd.: 28). Para él esta cuestión delata un problema genérico: dado que en español no había un término para definir la novela larga, dicha denominación se acabaría aplicando a las narraciones ficticias con visos de verosimilitud, como las bizantinas, donde los autores saben que dichas historias, siendo fingidas, pueden pasar por verdaderas al producir en los lectores el mismo efecto que aquellas: admiración, ejemplaridad y deseo de imitación o emulación ${ }^{17}$.

Lo que no contradiremos, pero tal vez merezca la pena considerar que la apostilla de verdadera de la que se vale Bernal nos pone delante de un problema que va más allá de la inserción de su obra en los habituales esquemas evolutivos de los manuales de literatura. Para Juan Carlos Rodríguez (2003: 80), cuya lectura compartimos, lo que queda patente aquí es la «importancia de la mirada literal (del "yo" que narra literalmente lo que ve)», y eso es un problema bien distinto y si cabe mucho más fascinante, en la medida en que delata ni más ni menos que «la aparición de la vida cotidiana como realidad tangible y común» (ibíd.: 81).

No por casualidad la mirada de Bernal tiende a la desacralización como la de Gómara tiende a la sacralización. En el caso del primero, es delicioso recorrer los pasajes en los que se empeña en narrar precisamente eso, lo que literalmente ve, algo que no nos atreveremos a establecer si lo convierte en novelista o no, pero que sin duda lo aleja de la mirada del cronista entendida en sentido lato, en la medida en que el cronista percibe el mundo como una sombra de los designios de la divinidad, como un Libro de la Naturaleza en cuyos caracteres Dios ha escrito una signatura, una similitud que propicia el

17 Y así escribirá: «si la primera intención de Bernal era redactar una prolija corónica a partir del memorial, va a acabar escribiendo una historia verdadera en todos los sentidos de la palabra, pues ha sido testigo de vista e informante, es una narración larga, refleja los principales hechos del descubrimiento y conquista de México y otras regiones limítrofes, y se presenta a sí mismo y a sus compañeros (en menor medida a los jefes) como personajes modélicos de una historia verdadera quasibizantina, o sea, como un grupo de hombres que, merced a su peregrinatio y tras muchas aventuras, alcanzaron el doble propósito moral: engrandecer el Imperio y llevar la fe a Ultramar. Tampoco es desdeñable el componente épico, cifrado aquí en la intervención divina, que legitima a su vez el historiográfico y el denominado "bizantino"» (Serés 2004: 29). Nótese que, de alguna manera, sobre todo al subrayar el componente épico, también Serés se desliza hacia la lectura literaria de la obra al estilo de Carlos Fuentes. 
surgimiento de la lectura alegórica. Poca alegoría, sin embargo, nos vamos a encontrar en esta narración de la batalla de Grijalba:

E como había allí mucha lama y ciénaga, no podíamos tan presto salir della. Y cargan sobre nosotros tantos indios, que con las lanzas a manteniente, y otros a flecharnos, hacían que no tomásemos tierra tan presto como quisiéramos; y también porque en aquella lama estaba Cortés peleando, y se le quedó un alpargate en el cieno, que no le pudo sacar, y, descalzo el un pie, salió a tierra; y luego le sacaron el alpargate y se calzó. Y entretanto que Cortés estaba en esto, todos nosotros, ansí capitanes como soldados, fuimos sobre ellos, nombrando a Señor Santiago y les hecimos retraer (XXXI, 115).

Nótese la diferencia abismal con Gómara, pues de la lectura figural de las hazañas de Cortés se pasa aquí a la narración del entretanto Cortés estaba en esto, solo que esto no es otra cosa que el capitán de Bernal en el nada heroico, y sí muy literal, acto de calzarse una alpargata que ha perdido en el cieno en el fragor de la batalla. Lejos de querer reivindicar este gusto por lo anecdótico como una esencia novelesca, subrayaremos que lo que sin duda queda patente es la sustitución de la mirada alegórica por la literal.

Sustitución que todavía se hace más explícita en el episodio en el que, según narra Gómara, aparece Francisco de Morla a caballo precediendo a Cortés. El cronista del I Marqués del Valle verá en él, cómo no, un signo de la intercesión divina. Primero - tirando de Aristóteles — valiéndose de la narración de la Historia:

A esta sazón llegó Cortés con los otros compañeros de a caballo, harto de rodear y de pasar arroyos y montes, pues no había otra cosa por allí. Le dijeron lo que habían visto hacer a uno de a caballo, y preguntaron si era de su compañía; y como dijo que no, porque a ninguno de ellos había podido venir antes, creyeron que era el apóstol Santiago, patrón de España. Entonces dijo Cortés: «Adelante, compañeros, que Dios es con nosotros y el glorioso San Pedro» (López de Gómara 2000a: 80).

Y luego, sin alejarse de los cánones de la Poética, dejando paso a la Poesía:

No pocas gracias dieron nuestros españoles cuando se vieron libres de las flechas y muchedumbre de indios, con quienes habían peleado, a nuestro Señor, que milagrosamente les quiso librar; y todos dijeron que vieron por tres veces al del caballo rucio picado pelear en su favor contra los indios, según arriba queda dicho; y que era Santiago, nuestro patrón. Hernán Cortés quería mejor que fuese San Pedro, su especial abogado; pero cualquiera que de ellos fuese, se tuvo a milagro, como de veras pareció; porque, no solamente lo vieron los españoles, sino también los indios lo notaron por el estrago que en ellos hacía cada vez que arremetía a su escuadrón y porque les parecía que los cegaba y entorpecía. De los prisioneros que se tomaron se supo esto (80-81). 
Pero no, no todos los españoles lo tuvieron tan a milagro, como muestra la retranca de Bernal, sencillamente gloriosa, al replicarle al cronista de Cortés en su narración del mismo episodio:

Aquí es donde dice Francisco López de Gómara que salió Francisco de Morla en un caballo rucio picado, antes que llegase Cortés con los de los caballos, y que eran los santos apóstoles Señor Santiago, o Señor San Pedro. Digo que todas nuestras obras y vitorias son por mano de Nuestro Señor Jesucristo, y que en aquella batalla había para cada uno de nosotros tantos indios, que a puñadas de tierra nos cegaron, salvo que la gran misericordia de Nuestro Señor en todo nos ayudaba; y pudiera ser que los que dice el Gómara fueran los gloriosos Apóstoles Señor Santiago o Señor San Pedro, e yo, como pecador, no fuese dino de lo ver. Lo que yo entonces vi y conocí fue a Francisco de Morla en un caballo castaño, que venía juntamente con Cortés, que me paresce que agora que lo estoy escribiendo se me representa por estos ojos pecadores toda la guerra segund y de la manera que allí pasamos (XXXV, 123-124).

Sucede que, si Gómara convierte a Cortés en una figura que se desempeña dentro de un concepto sacralizador de la historia, en Bernal es la vida cotidiana, aunque su cotidianidad sea la guerra, lo que queda inscrito en el relato, segund y de la manera que alli pasamos.

\section{CONCLUSIÓN}

No consideramos que sea exagerado concluir que esa, la sencilla acción de ver por estos ojos, es la clave enunciativa de todo el relato de Bernal. Incluso cuando este abandona la forma del memorial de guerras para reclamar su mérito al rey valiéndose, esta vez, de un diálogo con la fama que se pretende más o menos alegorizante, nosotros leemos: «Y digo otra vez que yo, yo, yo, dígolo tantas veces, que yo soy el más antiguo, y lo he servido como muy buen soldado a $\mathrm{Su}$ Majestad» (CCX, 1054). Es cierto, como de alguna manera intenta demostrar Cortínez, que el pasado se recupera a través de la escritura y que con ello se hace presente. No por nada Bernal puntualiza aquello de ayer pasó lo que verán en mi Historia, pero los matices que debemos poner aquí no son menores.

La crónica medieval se enuncia bajo la idea de que, de los tres tiempos, pasado, presente y futuro, «non puede omne seer cierto fueras da quel que es pasado» (Alfonso X 1999: 103), según leemos en el prólogo de la General Estoria alfonsí. Por contraste, y a diferencia de lo que cree Cortínez, en la Historia verdadera no se trata tanto de las dificultades para recuperar la memoria de tiempos pretéritos como de un sutil deslizamiento desde el pasado como única fuente de certeza al presente como única realidad existente, observable, testimoniable (y de ahí el ayer pasó lo que verán, pensamos). Si además 
el pasado ya está escrito bajo la forma de la auctoritas y toda escritura histórica no es, en la visión de ese lector atento y erudito tanto de la tradición como de la Escritura que es Gómara, sino una variación de lo enunciado en la Escritura, en el caso de Bernal la gran diferencia radicará en que enuncia su relato ya no como variación de la tradición escrituraria de la crónica sino como transcripción sobre el papel de lo que el ojo ve, sin mediación de la Escritura.

En la corónica se suele rehacer vagamente, o no tan vagamente, la idea ciceroniana de la Historia magistra vitae et testis temporum, pero siempre para narrar la historia desde arriba, pues toda historia es en última instancia hagiografía de los santos, reyes, nobles, caballeros, capitanes o cualesquiera otras figuras de un repertorio que a buen seguro dominaba López de Gómara, pero no tanto un Bernal Díaz del Castillo que se inserta a sí mismo en el orden de los sin letras. De ahí que solo podamos reprocharle a Guillermo Serés, en una modesta queja ante lo que consideramos es, ante todo, un imponente trabajo de edición, que se haya conformado con destinar a pie de página el prólogo donde Bernal afirma que no son cuentos viejos ni historias de romanos de más de setecientos años lo que él cuenta, alejándose así sin pretenderlo de la visión figural sacralizadora de la historia. También al comienzo de la ya mencionada General estoria leemos esto: "Natural cosa es de cobdiciar los omnes saber los fechos que acahescen en todos los tiempos» (Alfonso X 1999: 103). Algo que no es sino una glosa de la Metafísica (I, 980a, 21) de Aristóteles: «Omnes homines natura scire desiderant» (Aristóteles 1998: 3).

López de Gómara abundaría en esta necesidad de indagar en los hechos del pasado para extraer de ellos la nombradía o, dicho de otra manera, de narrar la Historia para reconocer los designios de la Poesía. Bernal, como poco después diría Cervantes, no parece andar a la búsqueda de auctores que digan lo que él ya sabía decir sin ellos. Para corroborar lo que había visto con sus ojos y llevarlo al papel no necesitaba ya ni tan siquiera al filósofo por antonomasia, porque como los mayas de «El eclipse», el memorable cuento de Augusto Monterroso (1998: 56), también él todo lo había «previsto y anotado en sus códices sin la valiosa ayuda de Aristóteles».

\section{BIBLIOGRAFÍA CITADA}

Adorno, Rolena (1988). «Discourses on Colonialism: Bernal Díaz, Las Casas, and the Twentieth-Century Reader», Modern Language Notes. CIII, 2, pp. 239-258. https://doi. org/10.2307/2905341

Adorno, Rolena (1992). «The Discursive Encounter of Spain and America: The Authority of Eyewitness Testimony in the Writing of History», The William and Mary Quarterly. XLIX, 2, pp. 210-228. https://doi.org/10.2307/2947270

Agustín, Santo (2004). La Ciudad de Dios (1. ${ }^{\circ}$, ed. Victorino Capanaga. 5. ${ }^{a}$ ed. Madrid: Biblioteca de Autores Cristianos. 
Alfonso X, rey de Castilla (1999). Prosa histórica, ed. Benito Brancaforte. 3. a ed. Madrid: Cátedra.

Angulo-Cano, Yanira (2010). «The Modern Autobiographical "I" in Bernal Díaz del Castillo», Modern Language Notes. CXXV, 2, pp. 287-304. https://doi.org/10.1353/mln.0.0251

Aristóteles (1998). Metafisica, ed. Valentín García Yebra. 2. ${ }^{a}$ ed. Madrid: Gredos.

Auerbach, Erich (1996). Mímesis. La representación de la realidad en la literatura occidental. 3. a ed. México: Fondo de Cultura Económica.

Brody, Robert (1987). «Bernal's Strategies», Hispanic Review. LV, 3, pp. 323-336. https:// doi.org/10.2307/473692

Caillet-Bois, Julio (1960). «Bernal Díaz del Castillo, o de la Verdad en la Historia», Revista Iberoamericana. 25, pp. 199-228. https://doi.org/10.5195/reviberoamer.1960.1980

Cortínez, Verónica (1991). "La construcción del pasado en la Historia verdadera de la conquista de la Nueva España y La casa de los espíritus», Hispanic Review. LIX, 3, pp. 317-327. https://doi.org/10.2307/474052

Cortínez, Verónica (1993). «"Yo, Bernal Díaz del Castillo”: ¿Soldado de a pie o idiota sin letras?», Revista Chilena de Literatura. 41, pp. 59-70.

Cortínez, Verónica (2000). Memoria original de Bernal Díaz del Castillo. México: oaK.

Díaz del Castillo, Bernal [1632]. Historia Verdadera de la Conqvista de la Nveva España. Escrita Por el Capitan Bernal Díaz del Castillo, Uno de sus Conquistadores. Sacada a liz, Por el P. M. Fr. Alonso Remon, Predicador y Coronista General del Orden de N. S. de la Merced, Redencion de Cavtivos. A la Catholica Magestad del Mayor Monarca D. Filipe IV. Rey de las Españas y Nuevo Mundo N. S. Madrid: Emprenta del Reyno.

Díaz del Castillo, Bernal (1877a). «Carta de Bernal Diaz del Castillo al Emperador D. Carlos dando cuenta de los abusos que se cometian en la gobernacion de las provincias del Nuevo Mundo. Santiago de Guatimala, 22 de febrero de 1552», en Cartas de Indias. Publicalas por primera vez el Ministerio de Fomento. Madrid: Imprenta de Manuel G. Hernandez, pp. 38-44.

Díaz del Castillo, Bernal (1877b). «Carta de Bernal Diaz del Castillo al Rey D. Felipe II, en la que denuncia algunos abusos cometidos con los indios, y pide se le nombre fiel-ejecutor de Guatimala, en atencion á los servicios que expone. Guatimala, 20 de febrero de 1558», en Cartas de Indias. Publícalas por primera vez el Ministerio de Fomento. Madrid: Imprenta de Manuel G. Hernandez, pp. 45-47.

Díaz del Castillo, Bernal (2011). Historia verdadera de la conquista de la Nueva España, ed. Guillermo Serés. Madrid: Real Academia Española-Galaxia Gutenberg.

Durán, Manuel (1992). «Bernal Díaz del Castillo: crónica, historia, mito», Hispania. LXXV, 4, pp. 795-804. https://doi.org/10.2307/343847

Estrada, Oswaldo (2009). La imaginación novelesca. Bernal Díaz entre géneros y épocas. Madrid-Frankfurt am Main: Iberoamericana-Vervuert.

Fuentes, Carlos (1990). «La épica vacilante de Bernal Díaz del Castillo», en Valiente mundo nuevo. Épica, utopía y mito en la novela hispanoamericana. México: Fondo de Cultura Económica, pp. 71-94.

Green, James Ray, Jr. (1983). «La retórica y la crónica de Indias: el caso de Bernal Díaz del Castillo», en A. David Kossoff, Ruth H. Kossoff, Geoffrey Ribbans, y José Amor y Vázquez (eds.), Actas del VIII Congreso de la Asociación Internacional de Hispanistas: 22-27 agosto 1983. Vol. 1. Madrid: Istmo, pp. 644-651.

Lazarillo de Tormes (2011), ed. Francisco Rico. Madrid: Real Academia Española-Galaxia Gutenberg.

López de Gómara, Francisco (2000a). La conquista de México, ed. José Luis de Rojas. Madrid: Dastin. 
López de Gómara, Francisco (2000b). Guerras de mar del emperador Carlos V. Compendio de lo que trata Francisco López en el libro que hizo de las guerras de mar de su tiempo, ed. Miguel Ángel de Bunes Ibarra y Nora Edith Jiménez. Madrid: Sociedad Estatal para la Conmemoración de los Centenarios de Felipe II y Carlos V.

Martínez Martínez, M. ${ }^{a}$ del Carmen (2010). «Francisco López de Gómara y Hernán Cortés: nuevos testimonios de la relación del cronista con los marqueses del Valle de Oaxaca», Anuario de Estudios Americanos. LXVII, 1, pp. 267-302. https://doi.org/10.3989/aeamer. 2010.v67.i1.339

Monterroso, Augusto (1998). Obras completas (y otros cuentos). Barcelona: Anagrama.

Pomian, Krzysztof (1990). El orden del tiempo. Madrid: Júcar.

Rodríguez, Juan Carlos (1990). Teoría e historia de la producción ideológica. Las primeras literaturas burguesas (siglo XVI). 2. ${ }^{\mathrm{a}}$ ed. Madrid: Akal.

Rodríguez, Juan Carlos (2001). La literatura del pobre. 2. ${ }^{a}$ ed. Granada: Comares.

Rodríguez, Juan Carlos (2003). El escritor que compró su propio libro. Para leer el Quijote. Barcelona: Debate.

Rodríguez Fernández, Mario (1966). «Bernal Díaz del Castillo y su concepto de verdad y realidad», Anales de la Universidad de Chile. 137, pp. 17-34.

Romero, Antonio F. (1988). «La "falacia antirretórica" en Bernal Díaz del Castillo», Revista de Crítica Literaria Latinoamericana. XIV, 28, pp. 337-344.https://doi.org/10.2307/4530406

Serés, Guillermo (2004). «Vida y escritura de Bernal Díaz del Castillo», Literatura: teoría, historia, crítica. 6, pp. 15-62.

Serés, Guillermo (2011a). «Bernal Díaz del Castillo y la "Historia verdadera"», en Bernal Díaz del Castillo, Historia verdadera de la conquista de la Nueva España. Madrid: Real Academia Española \& Galaxia Gutenberg, pp. 1117-1262.

Serés, Guillermo (2011b). «Presentación», en Bernal Díaz del Castillo, Historia verdadera de la conquista de la Nueva España. Madrid: Real Academia Española \& Galaxia Gutenberg, pp. IX-XII.

Turner, Guillermo (1993). «Los ojos, los oídos y la escritura de Bernal Díaz del Castillo», Historias. 31, pp. 21-30.

Valbuena Briones, Ángel (1958). «Épica e historia», Archivum: Revista de la Facultad de Filología. VIII, pp. 83-110.

Valcárcel Martínez, Simón (1989). «Una aproximación a Francisco López de Gómara», Caravelle. Cahiers du Monde Hispanique et Luso-Brésilien. LIII, pp. 7-24. https://doi. org/10.3406/carav.1989.2404

Wagner, Henry R. (1945). «Notes on Writings by and about Bernal Díaz del Castillo», The Hispanic American Historical Review. XXV, 2, pp. 199-211. https://doi. org/10.2307/2507952

Zamora, Margarita (1987). «Historicity and Literariness: Problems in the Literary Criticism of Spanish American Colonial Texts», Modern Language Notes. CII, 2, pp. 334-346. https://doi.org/10.2307/2905693

Fecha de recepción: 30 de octubre de 2015.

Fecha de aceptación: 18 de octubre de 2016. 